\title{
Anteseden Turnover Intention pada Karyawan Rumah Sakit "X" Bandung Barat
}

\author{
Albert Kurniawan Purnomo \\ Universitas Nurtanio Bandung \\ Email: alberstsmart9@gmail.com \\ Wanti Pebriani \\ Email:wanti.febriani11@gmail.com
}

\begin{abstract}
This study aims to discuss the perceived influence of organizational support on turnover intentions in hospital employees in West Bandung. This research was conducted on 67 respondents of hospital employees using quantitative methods. The data collection tool consists of a questionnaire. The data analysis technique used is descriptive statistical analysis using averages and simple linear regression analysis using the IBM SPSS24 program. The results of this study indicate that the perception of organizational support at Hospital $X$ is categorized quite high and considered a significant influence between the perception of organizational support for turnover intention in Hospital employees. The result view negative relationships between variables. The perceived increase in organizational support will reduce turnover intentions.
\end{abstract}

Keywords: Antecedent, Perceived Organizational Support (POS), Turnover Intention.

\begin{abstract}
Abstrak
Penelitian ini bertujuan untuk menguji pengaruh perceived organizational support terhadap turnover intention pada karyawan rumah sakit di Bandung Barat. Penelitian ini dilakukan pada 67 responden karyawan rumah sakit dengan menggunakan metode kuantitatif. Alat pengumpul data berupa kuesioner. Teknik analisis data yang digunakan yaitu teknik analisis statistik desktiptif dengan menggunakan rata-rata dan analisis regresi linier sederhana dengan menggunakan program IBM SPSS24. Hasil penelitian ini menunjukkan bahwa perceived organizational support pada rumah sakit berada dikategori cukup tinggi dan terdapat pengaruh yang signifikan antara perceived organizational support terhadap turnover intention pada karyawan rumah sakit. Dari hasil terlihat, terdapat hubungan yang negatif antara kedua variabel. Peningkatan perceived organizational support akan menurunkan tingkat turnover intention.
\end{abstract}

Kata kunci: Anteseden, Perceived Organizational Support (POS), Turnover Intention

\section{Pendahuluan}

Tujuan perusahaan dapat tercapai, jika perusahaan mampu memperhatikan dan memelihara tenaga kerjanya agar memiliki kualifikasi yang baik sehingga tidak memiliki keinginan untuk meninggalkan perusahaan (turnover intention), (Ardana dalam Kusuma \& Mujiati, 2017:57). Sumber daya manusia andal yang dimiliki oleh perusahaan memberikan keuntungan tersendiri, namun seringkali dalam perusahaan ada karyawan yang tidak mengerahkan seluruh kemampuan yang dimiliki untuk mencapai tujuan perusahaan karena adanya keinginan untuk pindah ke perusahaan lain, hal ini menyebabkan tingkat turnover intention karyawan dalam lingkungan operasional perusahaan sering terjadi (Rahayu dalam Putra dan Sauna, 2016:62).

Turnover intention karyawan yang diungkapkan oleh Rivai dalam Agustini dkk (2017:252) adalah keinginan karyawan untuk meninggalkan organisasi secara sukarela atas kemauan mereka sendiri". Tett dan Meyer dalam Putra dan Sauna (2016:61-62) mengemukakan turnover intention adalah kesadaran untuk memiliki keinginan mencari alternatif pekerjaan di organisasi lain. Turnover karyawan yang tinggi nantinya akan berdampak merugikan organisasi. Campbell, et al (2014 : 259) mengemukakan turnover intention adalah proses berpikir tentang 
berhenti dari suatu pekerjaan, berencana meninggalkan, atau merasakan keinginan untuk meninggalkan.

Lum at al dalam Putra dan Sauna, (2016:26) mengemukakan mengenai dimensi turnover intention yang diantaranya pikiran untuk mencari pekerjaan di perusahaan lain, mencari pekerjaan di bidang yang sama di perusahaan lain. Karyawan yang berniat meninggalkan perusahaan akan melihat segala sesuatunya menjadi bahan pertimbangan. Pada akhirnya, karyawan akan membuat suatu keputusan untuk menemukan pekerjaan baru di tahun depan.

Saat ini upaya untuk mengumpulkan tenaga kerja yang handal dengan kualitas baik semakin sulit, terlebih lagi untuk mempertahankan karyawan, maka dari itu perusahaan harus senantiasa memberikan dukungan-dukungan yang bersifat positif terhadap para karyawan, sehingga karyawan merasa bahwa dirinya didukung oleh organisasinya, hal tersebut disebut dengan perceived organizational support (POS) (Putra dan Sauna, 2016:27).

Robbins (2015:110) mengemukakan bahwa perceived organizational of support (POS) adalah tingkatan dimana para karyawan percaya bahwa perusahaan menghargai kontribusi para karyawan dan peduli terhadap masa depan mereka. Senada dengan hal tersebut, Caesens (2014:59) berpendapat sebuah teori dukungan organisasi atau perceived organizatonal of support disimpulkan dari pendekatan pertukaran sosial untuk menggambarkan hubungan karyawan dan organisasi. Karyawan mengakui dukungan yang mereka peroleh dari organisasi, organisasi merasa bahwa mereka memiliki kewajiban untuk itu dan perceived organizational support merupakan tingkat dimana para pekerja memercayai organisasi menilai kontribusinya dan peduli mengenai kesejahteraan mereka (Robbins, 2015:49).

Perceived Organizational Support (POS) adalah tingkat dimana karyawan merasa organisasi yang mempekerjakan mereka akan memberikan kompensasi yang pantas atas usaha mereka, membantu ketika mereka membutuhkan, membuat pekerjaan mereka menjadi menarik dan merangsang serta menciptakan kondisi kerja yang baik (Putra dan Sauna,2016:28). Penelitian Kalidass \& Bahron (2015) menjelaskan Perceived Organizational Support (POS) memberikan pengaruh negatif dan signifikan terhadap turnover intention. Kusuma \& Mujiati (2017) juga menyatakan Perceived Organizational Support (POS) memberikan pengaruh negatif dan signifikan terhadap turnover intention. Oktaviani \& Budiono (2018) dalam penelitiannya menyatakan Perceived Organizational Support berpengaruh signifikan negatif terhadap Turnover Intention. Dari beberapa literatur terdahulu, membuat peneliti tertarik melakukan penelitian, pada sektor jasa.

Sumber daya manusia, terutama pada organisasi yang bergerak di bidang jasa, telah menjadi faktor utama dalam keberhasilan pencapaian tujuannya. Hal ini semakin nyata pada organisasi yang secara langsung berinteraksi dengan konsumen yang membutuhkan jasa tersebut. Pada organisasi rumah sakit, misalnya, para pasien secara langsung merasakan pelayanan atau jasa yang diberikan oleh organisasi melalui para karyawannya. Hal- hal yang dilihat dan dirasakan oleh konsumen menggambarkan kualitas pelayanan mereka dan juga kualitas rumah sakit tersebut. Rumah Sakit X Bandung Barat yang menjadi tempat penelitian memiliki 200 karyawan dan diketahui setiap tahunnya ada masalah keluar masuk karyawan lama dan baru. Hal tersebut tercermin berdasarkan data turnover tahun 2017 dan tahun 2018 sehingga membuat pihak manajemen merasa sulit dalam mengatur pola kerja dan hal ini diduga karena faktor perceived organizational support yang dialami karyawan. Berikut adalah data turnover intention dalam persentase 2017 : 0,56\%, dan di tahun 2018 : meningkat menjadi 0,74\%. 
Saat ini tingginya tingkat turnover intention telah menjadi masalah serius bagi banyak perusahaan, bahkan beberapa perusahaan mengalami frustasi ketika mengetahui proses rekrutmen yang telah berhasil menjaring staf yang berkualitas pada akhirnya ternyata menjadi sia-sia karena staf yang direkrut tersebut telah memilih pekerjaan di perusahaan lain (Handaru $\&$ Nailul dalam Putra dan Sauna, 2016:62-63).

Penelitian ini bertujuan untuk mengetahui:

1. Perceived organizational support (POS) di Rumah Sakit X Bandung Barat.

2. Turnover Intention karyawan di Rumah Sakit X Bandung Barat.

3. Pengaruh perceived organizational support (POS) terhadap turnover intention karyawan di Rumah Sakit X Bandung Barat.

\section{Literature Review}

\section{Perceived organizational support}

Menurut Eisenberger dan Rhoades, dalam Ningrum (2013:32), Perceived organizational support merupakan keyakinan umum karyawan mengenai sejauh mana organisasi memberikan penghargaan kontribusi dan peduli atas kesejahteraan karyawan.

Perceived organizational support yang dirasakan karyawan ini dinilai sebagai kepastian akan tersedianya bantuan dari organisasi ketika karyawan membutuhkan dukungan untuk pelaksanaan tugas agar dapat berjalan secara efektif serta untuk menghadapi situasi - situasi yang mengandung tekanan.

Perceived organizational support merupakan tingkat dimana para pekerja memercayai organisasi menilai kontribusinya dan peduli mengenai kesejahteraan mereka (Robbins, 2015:49).

Arshadi dalam Mohamed dan Ali (2015:12) berpendapat Perceived Organization Support (POS) merupakan bagaimana organisasi menilai kontribusi karyawan dan peduli terhadap mereka. Perceived Organizational Support (POS) juga merupakan kepercayaan karyawan tentang tingkat komitmen organisasi terhadap karyawan mereka. Perceived Organizational Support (POS) mempertimbangkan kehidupan anggota organisasi, mengapresiasi kontribusi dan akan membantu mereka apapun masalah yang mereka hadapi.

Eisenberger, dalam Elayati (2015:36), mengemukakan aspek-aspek dalam perceived organizational support, antara lain :

1. Dukungan atasan

Keadaan dimana karyawan menerima perhatian khusus dan kesejahteraan dari manager atau atasannya. Sejauh mana atasan memberi dorongan pada karyawannya dalam meningkatkan potensi diri dan menerapkan kemampuan karyawan ke dalam tempat kerja.

2. Penghargaan

Sesuatu yang di berikan pada karyawan jika karyawan tersebut telah melakukan pekerjaan tidak hanya pada tugas pokoknya saja, tetapi juga bekerja lebih dengan hasil yang memuaskan demi kemajuan organisasi. Penghargaan biasanya diberikan dalam bentuk gelar, sertifikat, plakat atau pita.

3. Kondisi kerja

Kondisi atau keadaan lingkungan kerja di suatu perusahaan yang menjadi tempat bekerja para karyawan yang bekerja di dalam lingkungan tersebut. Karyawan akan merasa puas apabila karyawan merasakan kondisi kerja yang menyenangkan, aman, dan kondusif, maka 
karyawan akan cenderung menyukai pekerjaannya dan saling membantu sesama karyawan agar dapat mempermudah menyelesaikan pekerjaan.

Meiwintar (2016:45) dalam penelitiannya menyatakan bahwa, persepsi terhadap dukungan organisasi dapat berdampak pada faktor-faktor sebagai berikut:

1. Kepuasan karier

Pegawai merasa termotivasi dan puas dengan kariernya ketika merasa bahwa organisasi mendukung dan ketika ada persepsi bahwa organisasi memikirkan tentang kesejahteraan pegawai. Penelitian Latif dan Sher (2012:68) menemukan pengaruh yang signifikan antara persepsi terhadap dukungan organisasi dengan kepuasan karir pegawai.

2. Kinerja

Adanya persepsi terhadap dukungan organisasi pada pegawai akan menimbulkan berbagai konsekuensi mengenai kinerja. Afzali, dkk (2014:46) menyimpulkan dalam penelitiannya bahwa pegawai dengan persepsi positif pada dukungan organisasi akan meningkatkan peran kinerjanya.

3. Burn out

Persepsi terhadap dukungan organisasi berpengaruh pada burnout pada subjek perawat dalam penelitian Rowley and Purell dalam Eze, (2014:26). Penelitian tersebut menjelaskan bahwa persepsi terhadap dukungan organisasi berpengaruh pada burnout perawat. Perawat yang merasa rendah dukungan organisasi mengalami tingkat burnout yang tinggi daripada perawat yang merasakan tinggi dukungan organisasi pada pegawai.

4. Komitmen organisasi

Teori dukungan organisasi menyebutkan bahwa dalam hubungan pertukaran pegawai dan pemberi kerja, pegawai yang percaya bahwa pegawai telah menerima dukungan dari organisasi dalam level yang tinggi cenderung membalas dengan sikap kerja yang positif dan perilaku yang menguntungkan organisasi.

\section{Turnover Intention}

Kartono (2017:44) menjelaskan turnover intention merupakan keinginan pegawai untuk mengundurkan diri secara sukarela dari organisasi atau perusahaan atau dianggap sebagai gerakan karyawan untuk mengundurkan diri dari organisasi. Indikasi turnover intention antara lain adalah indikasi, antara lain: kecenderungan untuk meninggalkan perusahaan (tendency to leave the company), kemungkinan untuk mencari pekerjaan lain (possibility to find another job), kemungkinan untuk berpikir keluar dari perusahaan (possibility to think out of the company), kemungkinan untuk berpikir keluar dari perusahaan dalam waktu dekat (possibility to think out of the company in the near time). Kemungkinan untuk berpikir keluar dari perusahaan jika ada kesempatan lebih baik (possibility to think out of the company if there is any better opportunity).

Kartono (2017:47) juga menjelaskan bahwa penyebab turnover intention bisa berasal dari faktor internal dan eksternal. Faktor internal yang dapat menjadi penyebab intensi turnover adalah ketidakpuasan kerja, kurangnya dukungan organisasi seperti kondisi lingkungan yang kurang kondusif, jam kerja yang panjang dengan pembayaran minimum dan program pelatihan karyawan yang buruk. Faktor eksternal yang mendorong kemunculan tujuan turnover intention karyawan adalah ekonomi negara, upah lebih baik di tempat lain, peningkatan pembayaran di industri lain,kekuatan ekonomi lokal dan regional.

Lum dkk dalam Dewi, dkk (2016:10) mendefinisikan turnover intention adalah keinginan individu keluar dari organisasi, keinginan individu serta mengevaluasi mengenai posisi 
seseorang berdasarkan ketidakpuasan untuk memengaruhi seseorang ketika keluar dan menemukan pekerjaan yang lainnya di luar perusahaan.

Indikasi terjadinya turnover intention menurut Harnoto dalam Alfiyah, (2013:35) adalah:

1. Absensi yang meningkat

Pegawai yang berkeinginan untuk melakukan pindah kerja, biasanya ditandai dengan absensi yang semakin meningkat. Tingkat tanggung jawab pegawai dalam fase ini sangat kurang dibandingkan dengan sebelumnya.

2. Mulai malas bekerja

Pegawai yang berkeinginan untuk melakukan pindah kerja, akan lebih malas bekerja karena orientasi pegawai ini adalah bekerja di tempat lainnya yang dipandang lebih mampu memenuhi semua keinginan pegawai bersangkutan.

3. Peningkatan terhadap pelanggaran tata tertib kerja

Berbagai pelanggaran terhadap tata tertib dalam lingkungan pekerjaan sering dilakukan pegawai yang akan melakukan turnover. Pegawai lebih sering meninggalkan tempat kerja ketika jam-jam kerja berlangsung, maupun berbagai bentuk pelanggaran lainnya.

4. Peningkatan protes terhadap atasan

Pegawai yang berkeinginan untuk melakukan pindah kerja, lebih sering melakukan protes terhadap kebijakan-kebijakan perusahaan kepada atasan. Protes yang ditekankan biasanya berhubungan dengan balas jasa atau aturan lain yang tidak sependapat dengan keinginan pegawai.

5. Perilaku positif yang sangat berbeda dari biasanya

Biasanya hal ini berlaku untuk pegawai yang karakteristik positif. Pegawai ini mempunyai tanggung jawab yang tinggi terhadap tugas yang dibebankan, dan jika perilaku positif pegawai ini meningkat jauh dan berbeda dari biasanya justru menunjukkan pegawai ini akan melakukan turnover.

Lichtenstein dalam Mufidah, (2016:54) menyebutkan tiga aspek turnover intention yaitu:

1. Adanya kesempatan untuk meninggalkan organisasi.

2. Ada keinginan untuk meninggalkan pekerjaan yang sekarang.

3. Berencana untuk mencari pekerjaan baru dalam waktu dekat.

Kuncoro dalam Kartono (2017:44) menyatakan bahwa indikator turnover yaitu:

1. Intention to quit (niat untuk keluar) mencerminkan individu berniat untuk keluar adalah dilihat dari perilaku seseorang selama bekerja, biasanya diawali dengan perilaku absensi dan kemangkiran yang tinggi sebelum seseorang menentukan sikap untuk keluar dari organisasi.

2. Job search (pencarian pekerjaan) mencerminkan individu berkeinginan untuk mencari pekerjaan lain, pada umumnya diawali dengan mencari tambahan penghasilan di luar organisasi.

3. Thinking of quit (memikirkan keluar) mencerminkan individu untuk memikirkan sebelum mengambil sikap keluar, ia akan berpikir dalam rangka keputusannya tersebut, keluar dari pekerjaannya atau tetap berada di lingkungan pekerjaannya.

\section{Model Penelitian dan Hipotesis}

Model penelitian dapat digambarkan sebagai berikut:

Gambar 1. Model Penelitian

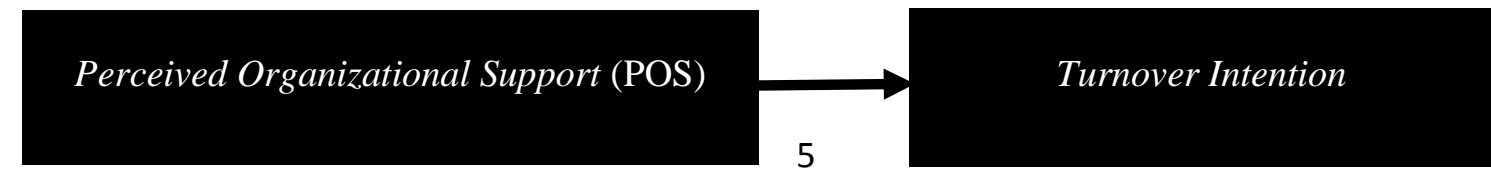


Perceived Organizational Support (POS) memberikan pengaruh negatif dan signifikan terhadap turnover intention telah diteliti Oktaviani \& Budiono (2018); Putra dan Suana (2016); dan juga Bitha \& Ardana (2017). Beberapa penelitian terdahulu, memberikan penguatan bagi peneliti untuk membuat hipotesis sebagai berikut: Terdapat pengaruh negatif dan signifikan Perceived Organizational Support (POS) terhadap Turnover Intention karyawan Rumah Sakit X Bandung Barat.

\section{Metode Penelitian}

Metode penelitian yang digunakan adalah metode penelitian eksperimen dan survei. Metode penelitian eksperimen merupakan metode penelitian yang digunakan mencari pengaruh tertentu sedangkan metode survei digunakan untuk mendapatkan data dari tempat tertentu yang alamiah, tetapi penelitian melakukan perlakuan dalam pengumpulan data misalnya dengan membagikan kuesioner, test, wawancara terstruktur dan sebagainya (Sugiyono, 2017:7).

Tingkat eksplanasi dan jenis penelitian ini adalah deskriptif-kuantitatif, studi kasus; yaitu mendeskripsikan fenomena turnover intention pada rumah sakit $\mathrm{X}$ di Bandung barat. Selanjutnya menganalisis besaran pengaruh variabel POS terhadap Turnover Intention karyawan (Aliya, 2019).

\section{Populasi dan Sampel}

Kurniawan (2019:158) populasi merupakan subjek yang berada pada suatu wilayah dan memenuhi syarat-syarat tertentu berkaitan dengan masalah penelitian.

Populasi dalam penelitian ini adalah seluruh karyawan rumah sakit berjumlah 200 responden. Sampel yaitu bagian dari jumlah dan karakteristik yang dimiliki oleh populasi tersebut (Sugiyono (2017 : 81). Sedangkan menurut besarnya sampel dalam penelitian ini ditetapkan dengan rumus Slovin:

$$
\begin{aligned}
& \mathrm{n}=\frac{\mathrm{N}}{1+\mathrm{N}(\mathrm{e})^{2}} \\
& \mathrm{n}=\frac{200}{1+200(0,10)^{2}}=67 \text { responden }
\end{aligned}
$$

Dalam penelitian ini, teknik sampling yang digunakan adalah non probability sampling dengan teknik yang diambil yaitu accidental sampling (Sampel Aksidental).

\section{Teknik Pengumpulan Data}

Kurniawan (2019:88) kuesioner adalah suatu alat pengumpul data yang berupa serangkaian pertanyaan tertulis yang diajukan kepada subjek (responden) untuk mendapatkan jawaban secara tertulis.

Kuesioner tersebut berisi daftar pertanyaan operasional yang ditanyakan pada responden terpilih untuk menjawab hipotesis-hipotesis yang dikembangkan sesuai dengan tujuan penelitian. Kuesioner diberikan dalam bentuk daftar pertanyaan beserta jawabannya kepada 67 orang responden guna memperoleh tanggapan mengenai Percerived Organizational Support (POS) terhadap Turnover Intention karyawan rumah sakit X Bandung Barat.

\section{Definisi Operasional Variabel}

Variabel Percerived Organizational Support (POS) memiliki 3 (tiga) dimensi yaitu dukungan atasan; penghargaan; dan kondisi kerja. Dukungan atasan dijabarkan ke dalam 2 (dua) 
indikator. Penghargaan 2 (dua) indikator. Kondisi kerja juga 2 (dua) indikator (Ningrum, 2013:32). Turnover intention dapat dijabarkan ke dalam 3 (tiga) dimensi yaitu (1) thinking of quitting, dengan 2 (dua) indikator ; (2) intention to search for alternatives dengan 2 (dua) indikator; dan (3) intention to quit dengan 2 (dua) indikator.

\section{Hasil dan Pembahasan}

Teknik analisis data dalam penelitian ini menggunakan analisis regresi, di dalam penelitian ini terdapat variabel independen / anteseden (Perceived organization support), dan variabel dependen (Turnover intention).

Hasil Analisis

Pengujian Model

Tabel 1. Hasil Uji Validitas

\begin{tabular}{lllc}
\hline Item & r hitung & r kritis & Kesimpulan \\
\hline POS1 & 0,833 & 0,300 & Valid \\
\hline POS2 & 0,885 & 0,300 & Valid \\
\hline POS3 & 0,768 & 0,300 & Valid \\
\hline POS4 & 0,812 & 0,300 & Valid \\
\hline POS5 & 0,738 & 0,300 & Valid \\
\hline POS6 & 0,459 & 0,300 & Valid \\
\hline TI1 & 0,691 & 0,300 & Valid \\
\hline TI2 & 0,719 & 0,300 & Valid \\
\hline TI3 & 0,824 & 0,300 & Valid \\
\hline TI4 & 0,859 & 0,300 & Valid \\
\hline TI5 & 0,814 & 0,300 & Valid \\
\hline TI6 & 0,729 & 0,300 & Valid
\end{tabular}

Sumber: Hasil Pengolahan IBM SPSS (2019)

Dari pengujian validitas, telah memenuhi syarat minimal yaitu di atas 0,30 . Hal ini mendukung syarat validitas (Mohajan, 2017:17). Nilai validitas berkisar nilai 0,459-0,885.

Tabel 2. Hasil Uji Reliabilitas

\begin{tabular}{cccc}
\hline Variabel & $\begin{array}{c}\text { Cronbach } \\
\text { Alpha }\end{array}$ & Kriteria & Kesimpulan \\
\hline POS & 0,800 & 0,600 & Reliabel \\
\hline TI & 0,894 & 0,600 & Reliabel \\
\hline
\end{tabular}

Sumber: Hasil Pengolahan IBM SPSS (2019)

Dari pengujian reliabilitas, memiliki syarat Cronbach Alpha minimal 0,70 (Sekaran \& Bougie, 2016:290), dari hasil pengujian reliabilitas, semua variabel memenuhi syarat dengan nilai di atas 0,70 yaitu 0,800 dan 0,894 .

\section{Pengujian Deskriptif}

Dalam point ini akan dijabarkan pengujian secara deskriptif dari 2 (dua) variabel yaitu Perceived Organizational Support (POS), dan Turnover Intention.

Berikut hasil uji deskriptif dari kedua variabel : 
Tabel 3. Hasil Uji Deskriptif

\begin{tabular}{clll}
\hline Variabel & Indikator & Rata-Rata & Kesimpulan \\
\hline & & & \\
\cline { 2 - 4 } Perceived Organizational Support & POS 1 & 3,12 & Cukup Tinggi \\
\cline { 2 - 4 } & POS2 & 3,11 & Cukup Tinggi \\
\cline { 2 - 4 } & POS3 & 3,08 & Cukup Tinggi \\
\cline { 2 - 4 } & POS4 & 3,16 & Cukup Tinggi \\
\cline { 2 - 4 } & POS5 & 3,16 & Cukup Tinggi \\
\cline { 2 - 4 } Turnover Intention & POS6 & 3,37 & Cukup Tinggi \\
\cline { 2 - 4 } & POS & 3,17 & Cukup Tinggi \\
\hline & TI1 & 3,43 & Tinggi \\
\cline { 2 - 4 } & TI2 & 3,51 & Tinggi \\
\cline { 2 - 4 } & TI3 & 3,45 & Tinggi \\
\cline { 2 - 4 } & TI4 & 3,19 & Cukup Tinggi \\
\cline { 2 - 4 } & TI5 & 3,11 & Cukup Tinggi \\
\hline & TI6 & 3,03 & Cukup Tinggi \\
\hline & TI & 3,29 & Cukup Tinggi \\
\hline
\end{tabular}

Sumber: Hasil Pengolahan Ms. Excell (2019)

Klasifikasi rata-rata dan kesimpulan didasarkan pada Umar (2019) dan Purnomo (2019), yang membagi kriteria menjadi 5 (lima):

Tabel 4. Klasifikasi Kelas Interval

\begin{tabular}{|l|l|}
\hline Kriteria & Interval \\
\hline Sangat Tidak Tinggi & $1,00-1,80$ \\
\hline Tidak Tinggi & $>1,80-2,60$ \\
\hline Cukup Tinggi & $>2,60-3,40$ \\
\hline Tinggi & $>3,40-4,20$ \\
\hline Sangat Tinggi & $>4,20-5,00$ \\
\hline
\end{tabular}

Sumber: Umar (2019) \& Purnomo (2019)

\section{Hasil Pengujian Hipotesis}

Pengujian regresi sederhana

Tabel 5. Nilai R-Square

\begin{tabular}{|l|l|}
\hline Variabel Dependen & R Square \\
\hline Turnover Intention & 0,141 \\
\hline
\end{tabular}

Sumber: Hasil Pengolahan IBM SPSS (2019)

Hasil koefisien determinasi, besar pengaruh Perceived Organizational Support (POS) terhadap Turnover Intention adalah 0,141 atau $14,1 \%$. 


\section{Pengujian Inferesial}

Parameter pengukuran tentang ada tidaknya pengaruh dan signifikan secara parsial antara variabel bebas (Perceived organizational support) terhadap variabel terikat (Turnover intention) diketahui berdasarkan nilai-nilai dengan ketentuan sebagai berikut:

Tabel 6. Hasil Pengujian Model Persamaan

\begin{tabular}{|l|l|l|l|l|}
\hline Hipotesis & Coeff & t & Sig & Kesimpulan \\
\hline $\begin{array}{l}\text { POS berpengaruh negatif } \\
\text { terhadap Turnover Intention }\end{array}$ & $-0,415$ & $-3,264$ & 0,002 & Hipotesis diterima \\
\hline
\end{tabular}

Sumber: Hasil Pengolahan IBM SPSS (2019)

\section{Pembahasan}

Tabel 3, tabel 5, dan tabel 6 menjelaskan tentang nilai-nilai yang dapat digunakan untuk menguji hasil penelitian yaitu sebagai berikut :

1. Hasil perhitungan deskriptif pada variabel Perceived Organizational Support (POS) diperoleh hasil bahwa dari 6 (enam) indikator diindikasikan oleh responden dengan ratarata jawaban Cukup Tinggi. Hal tersebut tercermin dari pertanyaan mengenai variabel Perceived Organizational Support (POS) bahwa perusahaan akan menegur apabila karyawan tidak melakukan pekerjaan dengan baik.

2. Hasil perhitungan deskriptif pada variabel Turnover Intention karyawan diperoleh hasil bahwa dari 6 (enam) indikator diindikasikan oleh responden dengan rata-rata jawaban Cukup Tinggi. Hal tersebut tercermin dari pertanyaan mengenai variabel Turnover Intention bahwa selama ini perusahaan tidak memerhatikan jenjang karir dan kesejahteraan karyawan.

3. Dari hasil analisis koefisien determinasi dapat diketahui bahwa pengaruh Percerived Organizational Support (POS) terhadap Turnover Intention karyawan di rumah sakit X Bandung Barat tergolong rendah hanya 14,1\%. 85,9\% lainnya dipengaruhi faktor lain yang tidak difokuskan untuk diteliti. Dari perhitungan uji t maka didapatkan hasil bahwa hipotesis diterima. Percerived Organizational Support (POS) berpengaruh negatif dan signifikan terhadap Turnover Intention karyawan di rumah sakit X Bandung Barat.

Hasil riset ini sejalan dengan beberapa penelitian terdahulu. Penelitian sebelumnya telah dilakukan oleh beberapa peneliti diantaranya Kalidass dan Bahron (2015); Putra dan Suana (2016); Kusuma dan Mujiati (2017) menyatakan terdapat pengaruh signifikan dan negatif perceived organizational support (POS) terhadap turnover intention .

\section{Simpulan dan Saran}

Hasil penelitian ini dapat disimpulkan bahwa karyawan merasakan bahwa Rumah Sakit X Bandung Barat akan menegur apabila karyawan tidak melakukan pekerjaan dengan baik. Selain itu, karyawan Rumah Sakit X Bandung Barat memerhatikan jenjang karier dan kesejahteraan karyawan.

Perceived Organizational Support (POS) berpengaruh secara signifikan dan negatif terhadap Turnover Intention. Besar pengaruh Perceived Organizational Support (POS) terhadap Turnover Intention dalam penelitian ini rendah, kecil.

Berdasarkan hasil temuan, maka beberapa hal dapat disarankan kepada pihak Rumah Sakit X Bandung Barat dapat meningkatkan Perceived Organizational Support (POS) diantaranya 
adalah dengan memberikan penghargaan terhadap kontribusi karyawan seperti prestasi kerja, pemberian insentif dan bonus, melakukan pelatihan dan pengembangan sehingga keahlian dan karyawan bertambah. Berkaitan dengan karyawan yang berkeinginan untuk meninggalkan Rumah Sakit X Bandung Barat dalam beberapa bulan mendatang sebaiknya dapat memberikan jaminan kelangsungan kerja di perusahaan seperti fasilitas yang didapatkan karyawan, kompensasi, dan memberikan kepercayaan kerja untuk mengelola pekerjaannya. Bagi karyawan yang berkeinginan keluar, dapat disarankan melakukan konsultasi dengan manajemen dan tidak mengambil keputusan langsung sehingga tidak merugikan perusahaan.

\section{Daftar Pustaka}

Afzali, A., Motahari, A.A., Hatami-Shirkouhi, L. (2014). Investigating The Influence Of Perceived Organizational Support, Psychological Empowerment And Organizational Learning On Job Performance: An Empirical Investigation. Tehnički vjesnik 21, 3(2014), 623-629.

Agustini, dkk. (2017). Pengaruh Perceived Organizational Support terhadap Turnover Intention dengan komitmen organisasional sebagai variabel pemediasi. E-Jurnal Ekonomi dan Bisnis Universitas Udayana, 6(10).

Alfiyah. (2013). Faktor-faktor yang berhubungan dengan turnover intention perawat di Brawijaya women and children Hospital Jakarta tahun 2013. Skripsi. Universitas Islam Negri Syarif Hidayatullah-Fakultas Kedokteran dan Ilmu Kesehatan.

Aliya, S., \& Tobari, T. (2019) Pengaruh Pendidikan dan Pelatihan Terhadap Produktivitas Kerja Karyawan Bagian Produksi Pada PT. Semen Baturaja (Persero) Tbk Palembang. Jurnal Manajemen, Kepemimpinan, dan Supervisi Pendidikan, Volume 4, No.1, 97-103.

Arshadi, N., and Hayavi, G. (2014). The Effect of Perceived Organizational Support on Affective Commitment and Job Performance: Mediating role of OBSE. Procedia - Social and Behavioral Sciences, 84, 739-743. https://doi.org/10.1016/j.sbspro.2013.06.637.

Bitha, S., \& Ardana, I. (2017). Pengaruh keterikatan kerja, persepsi dukungn organisasional dan komitmen orgnisasional terhadap turnover intention karyawan Muji Motor. E-Jurnal Manajemen, 6(2), $919 \quad$ - $947 . \quad$ Retrieved from https://ojs.unud.ac.id/index.php/Manajemen/article/view/27408. Smith, Joe. (1999). One of Volvo's core values. [Online] Available: http://www.volvo.com/environment/index.htm (July 7, 2007).

Caesens, G., Marique, G., \& Stinglhamber, F. (2014). The relationship between perceived organizational support and affective commitment: More than reciprocity, it is also a question of organizational identification. Journal of Personnel Psychology, 13(4), 167173.

Campbell, et al. (2014). Internal efficiency and turnover intention: Evidence from local government in South Korea. Public Personnel Management. , 43(2), pp.259-282.

Dewi, R.S. (2016). Peranan Perceived Organizational Support terhadap Kepuasan kerja. Jurnal Ecopsy : Jurnal Ilmu Psikologi. DOI: 10.20527/ecopsy.v2i3.1925.

Elayati. (2015). Pengaruh Keadilan Imbalan Dan Gaya Kepemimpinan Berorientasi Tugas Terhadap Perceived Organizational Support Pada Sales PT. Perdana Cabang Semarang. Skripsi. Malang. Universitas Negeri Malang.

Kalidass, A. dan Bahron, A. (2015). The Relationship Between Perceived Supervisor Support, Perceived Organizational Support, Organizational Commitment And Employee Turnover Intention. International Journal of Business Administration. ISSN 1923-4007,E-ISSN $1923-4015$. 
Kartono. (2017). Personality, Empolee Engagement, Emotional Intellegece, Job Burnout pendekatan dalam melihat Turnover Intention. Yogyakarta: CV Budi Utama.

Kurniawan. (2019). Metode Riset untuk Ekonomi dan Bisnis: Teori, Konsep, dan Praktik Penelitian Bisnis. Bandung: Alfabeta.

Kusuma \& Mujiati, (2017). Pengaruh Perceived Organizational Support dan Komitmen Organisasional Terhadap Turnover Intention Karyawan di Hotel Alila Ubud. E-Jurnal Manajemen, 6(10), 5748-5774.

Latif, K.I., Sher, M. (2012). Perceived Organizational Support, Pay Satisfaction, and Supervisor Satisfaction Impact on Career Satisfaction. Abasyn Journal of Social Sciences Vol. 5 No. 1, 32-48.

Meiwintar. (2016). Hubungan Antara Persepsi Terhadap Dukungan Organisasi Dengan Komitmen Afektif Karyawan PT. Madurasa Nusaperdana. Skripsi. Yogyakarta. Universitas Sanata Dharma.

Mohajan, H. (2017): Two Criteria for Good Measurements in Research: Validity and Reliability. Published in: Annals of Spiru Haret University, Vol. 17, No. 4 (24 December 2017): pp. 56-82.

Mohamed, S.A., \& Ali, M. (2015). The Influence of Perceived Organizational Support on Employees' Job Performance. International Journal of Scientific and Research Publications, Volume 5, Issue 4, April 2015. ISSN 2250-3153.

Mufidah, L. (2016). Pengaruh Job Satisfaction Terhadap Turnover Intention Dengan Continuance Commitment Sebagai Variabel Intervening Pada Karyawan EF Sinergy Consultant. Surabaya: Skripsi Universitas Airlangga.

Ningrum, S. (2013). Pengaruh Perceived Organizational Support dan Kepuasan kerja Terhadap Turnover intentions. Semarang: IKIP PGRI.

Oktaviani, H, \& Budiono. (2018). Pengaruh Work Life Balance dan Perceived Organizational Support terhadap Turnover Intention melalui Organizational Commitment sebagai Variabel Intervening pada PT Berlian Jasa Terminal Indonesia. Jurnal Ilmu Manajemen Volume 6 Nomor 3 - Jurusan Manajemen Fakultas Ekonomi Universitas Negeri Surabaya.

Purnomo, A.K. (2019). Pengolahan Riset Ekonomi Jadi Mudah Dengan IBM SPSS. Surabaya: CV Jakad Publishing.

Putra dan Suana (2016).Pengaruh Perceived Organizational Support dan Job Insecurity Terhadap Turnover Intention Pada Karyawan di PT. Bali Mai Sho. E-Jurnal Manajemen, $5(10)$.

Robbins, S.P. dan Judge, T.A. (2015). Organizational Behavior $12^{\text {th }}$ edition. Pearson PrenticeHall.

Sekaran, U., \& Bougie, R. (2016). Research Methods for Business: A Skill Building Approach, $7^{\text {th }}$ Edition. Chichester, United Kingdom: Wiley.

Umar, H. (2019). Metode Riset Manajemen Perusahaan Langkah Cepat dan Tepat Menyusun Tesis dan Disertasi. Jakarta: Penerbit Gramedia Pustaka Utama.

\section{Acknowledgement}

Ucapan terima kasih disampaikan kepada pihak Universitas Nurtanio Bandung yang telah memberikan dukungan moril, semangat kepada peneliti. Kepada pihak rumah sakit yang telah berkenan untuk dijadikan tempat penelitian dan berpartisipasi dalam hal pengisian kuesioner.

\section{Copyright Disclaimer}

Copyright for this article is retained by the author(s), with first publication rights granted to the journal. 